\title{
VEGETABLE OILS FOR HIGH VOLTAGE INSULATION \\ BY
}

\author{
EZECHUKWU O. A., PhD, MNSE, MNIEEE \\ DEPARTMENT OF ELECTRICAL ENGINEERING \\ NNAMDI AZIKIWE UNIVERSITY AWKA \\ ezechukwuosieloka@gmail.com
}

$+2348064493088,+2348088078278$

\begin{abstract}
This paper discusses the findings of the study of the possibility of using some vegetable oils as high voltage insulation materials. Samples of palm oil (elaeis guineensis), palm kernel oil (elaeis guineensis), coconut oil (cocos nucifera), groundnut oil(Arachis hypogea) and local pear oil(dacryodes edulis) were obtained from Ekwulobia town, processed and tested. The results obtained showed exciting performance for palm oil, palm kernel oil and groundnut oil. Investigation on the dielectric strength of local pear oil (dacryodes eduli) is inconclusive because the sample collected was not sufficient for the tests.
\end{abstract}

Key words: Dielectric strength, Breakdown voltage, vegetable oil, insulation, moisture content.

\section{Council for Innovative Research}

Peer Review Research Publishing System

Journal: INTERNATIONAL JOURNAL OF COMPUTERS \& TECHNOLOGY

Vol 10, No 4

editor@cirworld.com

www.cirworld.com, member.cirworld.com 


\subsection{INTRODUCTION}

The mineral oils in use for high voltage insulation contain hydrocarbons and some proportions of sulphur and nitrogen. They can cause health problems (e.g cancer, etc) and are highly corrosive and dangerous to aquatic lives and crops. Mineral oils are in three categories;-

Paraffin: Methane $(\mathrm{CH} 4)$ is a gas-normal butane $(\mathrm{C} 4 \mathrm{H} 10)$ and iso butene.

Naphthene : It has ring structures with six carbon atoms (within six-member rings) or fourteen carbon atoms (within three member rings).

Aromatics: It has six-member ring structures and two groups: mono-aromatics (single rings) and poly-aromatics (two or more rings).

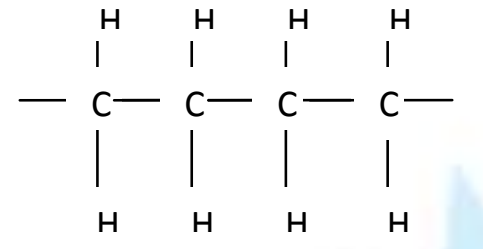

(a)Paraffin

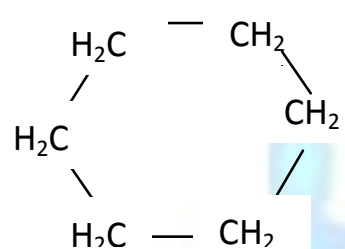

(b) Naphtene

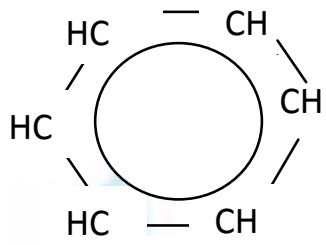

(c) Aromatic

\section{Fig 1: Structures of some mineral oils}

Transformer oil, made from petroleum product, has been used for cooling and insulation because of its dielectric qualities, but its hydrocarbon content and none-biodegradability make it hazardous to human beings, crops and aquatic lives. Thus good alternatives devoid of these bad effects are being sought for. One source of hope comes from the farm. Some vegetable oils have produced some promising results. One of such results is presented in this paper.

\subsection{Vegetable Oils:}

Fats and oils belong to a general group of compounds known as lipids. Fats are solid usually of animal origin while oils are liquids mainly from plants. Both are esters of the trihydric alkanol, propane 1,2,3-triol. Each molecule of propane - 1,2,3triol is esterified with three molecules of fatty acids [8]as shown in fig 2 .

$$
\begin{array}{ll}
\mathrm{RCOOH} H O-\mathrm{CH}_{2} & \mathrm{RCOOCH}_{2} \\
\mathrm{R}^{2} \mathrm{COOH}+\mathrm{HO}-\mathrm{CH}^{\prime} \longrightarrow & \mathrm{R}^{2} \mathrm{COOCH}+3 \mathrm{H}_{2} \mathrm{O} \\
\mathrm{R}^{\prime \prime} \mathrm{COOH} \mathrm{HO}-\mathrm{CH}_{2}^{\prime} & \mathrm{R}^{\prime \prime C O O C H} \\
\text { Fatty acid alkanol } & \text { ester water }
\end{array}
$$

"Fig 2: structures of some vegetable oils

Where R.R1 and R" can be the same or different. The fatty acids commonly found in lipids are long chain alkanoic acids of the general formula, $\mathrm{RCOOH}$ where $\mathrm{R}$ contain about 10 to 18 carbon atoms.

The terminal - $\mathrm{COOH}$ group is polar, hence the acid is able to dissolve in water. The carboxylic acid group ionizes in water to a certain degree to form hydrogen ion and carboxylate ion. Fatty acids are thus weak acids.

$$
\mathrm{RCOOH}(\mathrm{aq}) \quad \mathrm{RCO}(\mathrm{aq})+\mathrm{H}+(\mathrm{aq})
$$

The long alkyl group is non-polar, and so is not soluble in water. Fatty acids are divided into two groups: Saturated fatty acids

Unsaturated fatty acids

The saturated fatty acids have no double bonds in their hydrocarbon chain while the unsaturated fatty acids have one or more double bonds in their hydrocarbon chain.

Vegetable oils are complex mixture of propane -1,2,3-triol esters, their properties depend mainly on the proportion of each constituent. Vegetable oils have lower melting points than fats because they are composed of higher proportion of esters of unsaturated fatty acids.

\subsection{GOOD QUALITIES OF VEGETABLE OIL'}

Hygroscopic: Vegetable oils are hygroscopic because water molecules easily attach to the polar molecular bond. 
Lubricity: They have the capability of retarding friction and corrosion

Thermal stability: The higher bond energy linkage makes it stable to heat [10]

They have Low vapour pressure, low volatilities and high flash point.

Hydrolytic stability: Hydrolysis is the reverse action of esterification, so if the process in creating the vegetable fluids runs well then it also maintains the stability of the hydrolytic aspect.

High solvency

More research work is going on to improve the qualities of palm oil, palm kernel oil and groundnut oil. The coconut oil requires special treatment to improve its dielectric strength. Some factors affect the quality of vegetable oils: Besides wear out due to aging, the major breakdown elements include mechanical stress as can be seen in fig3.

Vegetable oils have poor pour point. They can be treated to improve on that quality. However they can flow excellently at temperatures of 300 and above.

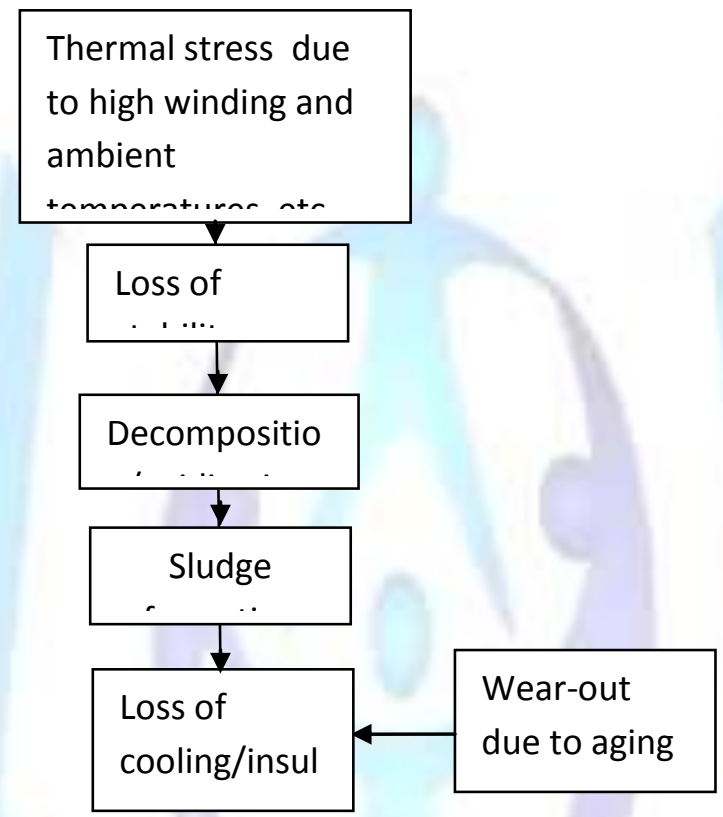

Fig3: Break down mechanism of insulating oil

In transformers, insulating oil plays the role of cooling and insulation. Therefore the life of a transformer depends partially on the quality and quantity of insulating oil. The same thing is applicable to some other electrical apparatus.

\subsection{TESTS}

\subsection{AGING TEST OR PEROXIDE VALUE}

This is an accelerated stress test conducted on a specimen to determine the wear- out of the specimen. The figures of the peroxide values of the vegetable oils are shown in table1

Table1: Aging test/ Peroxide values of oil samples

\begin{tabular}{|l|l|l|l|l|l|}
\hline \multirow{2}{*}{ S/N } & SAMPLE TYPE & \multicolumn{4}{l}{$\begin{array}{l}\text { PEROXIDE } \\
\text { VALUE mgE/Kg }\end{array}$} \\
\cline { 3 - 6 } & & 4 days & 14 days & 20 days & 30 days \\
\hline 1 & Transformer oil & 1.0 & 3.0 & 6.0 & 8.0 \\
\hline 2 & Palm kernel oil & 6.0 & 9.0 & 12.0 & 15.0 \\
\hline 3 & Palm oil & 10.0 & 16.0 & 28.0 & 30.0 \\
\hline 4 & Groundnut oil & 4.0 & 8.0 & 14.0 & 16.0 \\
\hline 5 & Coconut oil & 12.0 & 16.0 & 26.0 & 28.0 \\
\hline
\end{tabular}




\subsection{POUR AND FLASH POINTS}

The pour point of insulating oil is the temperature where the oil starts to freeze and the flash point is the temperature where the oil catches fire (point of ignition).

Table2: Pour and Flash points of oil samples

\begin{tabular}{|l|l|l|l|}
\hline \multirow{2}{*}{} & Sample type & \multicolumn{2}{|l|}{ Parameter } \\
\cline { 3 - 4 } & $\begin{array}{l}\text { Pour } \\
\text { point } \\
\text { (oC) }\end{array}$ & $\begin{array}{l}\text { Flash } \\
\text { point } \\
(\text { oC) }\end{array}$ \\
\hline 1 & $\begin{array}{l}\text { Transformer } \\
\text { oil }\end{array}$ & $\begin{array}{l}\text { Below } \\
00\end{array}$ & 270 \\
\hline 2 & $\begin{array}{l}\text { Palm kernel } \\
\text { oil }\end{array}$ & 30 & 340 \\
\hline 3 & Palm oil & 30 & 304 \\
\hline 4 & Groundnut oil & 28 & 340 \\
\hline 5 & Coconut oil & 30 & 340 \\
\hline
\end{tabular}

The transformer oil did not freeze at $0^{\circ} \mathrm{C}$ for 48 hours

\subsection{MOISTURE CONTENT}

Tests were carried out to determine the moisture content at certain temperatures

$1 \mathrm{~g}$ of the specimen was used as sample for the test

Let weight of petridish and oil sample before drying $=\mathrm{W} 1$

Weight of petridish \& sample after drying =W2

Weight of moisture = $\quad$ W1-W2

$\%$ moisture content $=\frac{W t \text { of } \text { moisture }}{W t \text { of } \text { specimen }} \times 100$

i.e $\%$ moisture content $=\frac{W 1-W 2}{1 g} \times 100$

Table3 Released moisture (\%) at different temperatures

\section{3,4 DIELECTRIC /VOLTAGE BREAK-DOWN TEST}

\begin{tabular}{|c|c|c|c|c|c|c|c|}
\hline \multirow[t]{2}{*}{ 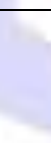 } & \multirow[t]{2}{*}{ SAMPLE TYPE } & \multicolumn{6}{|c|}{$\begin{array}{l}\text { TEMPERATURE } \\
(\mathrm{OC})\end{array}$} \\
\hline & & 10 & 30 & 50 & 100 & 150 & 200 \\
\hline 1 & Transformer oil & $\mathrm{NIL}$ & NIL & NIL & 32.3 & 29.11 & 10.3 \\
\hline 2 & Palm kernel oil & $\mathrm{NIL}$ & NIL & NIL & 12.65 & 11.83 & 2.0 \\
\hline 3 & Palm oil & NIL & NIL & NIL & 27.88 & 21.84 & 18.2 \\
\hline 4 & Groundnut oil & NIL & NIL & $\mathrm{NIL}$ & 4.6 & 8.9 & 5.8 \\
\hline 5 & Coconut oil & $\mathrm{NIL}$ & NIL & & 19.1 & 14.3 & 12.5 \\
\hline
\end{tabular}

Equipment used:

MAKE-Megger oil tester

Model- (OTS 60PB) oil tester set

Spherical electrode gap $=2.5 \mathrm{~mm}$

AMBIENT TEMPERATURE: $300 \mathrm{C}$

BS 148 (1984)

\subsubsection{METHOD OF TESTING}

Samples were subjected to heating (using electric heater), to remove moisture, before testing. 
Each oil sample was subjected to six tests at the intervals of 5 minutes and the average break-down values were recorded.

\section{(a) Sample 1- Transformer (mineral) oil}

Temperature $=300 \mathrm{C}$

Average break-down voltage $=50 \mathrm{Kv}$

Standard deviation $(\sigma)=5.1$

Dielectric loss factor $(\tan \sigma)=0.09$

(b) Sample2-Palm kernel oil.

Temperature $=30 \mathrm{oC}$

Average break-down voltage $=51 \mathrm{Kv}$

Standard deviation $(\sigma)=10.19$

Dielectric loss factor $(\tan \sigma)=0.18$

(c) Sample3-Palm oil.

Temperature $=30 \mathrm{oC}$

Average break-down voltage $=51 \mathrm{Kv}$

Standard deviation $(\sigma)=9.6$

Dielectric loss factor $(\tan \sigma)=0.17$

(d) Sample4-Groundnut oil.

Temperature $=30 \mathrm{oC}$

Average break-down voltage $=30 \mathrm{Kv}$

Standard deviation $(\sigma)=2.79$

Dielectric loss factor $(\tan \sigma)=0.05$

(e) Sample5-Coconut oil.

Temperature $=30^{\circ} \mathrm{C}$

Average break-down voltage $=4.0 \mathrm{Kv}$

Standard deviation $(\sigma)=2.6$

Dielectric loss factor $(\tan \sigma)=0.05$

\subsubsection{RESULTS AT A GLANCE}

All the results obtained are displayed in table5 for easy comparison.

Table5: Summary of all the results

\begin{tabular}{|l|l|l|l|l|l|l|}
\hline & Sample type & $\begin{array}{l}\text { Average } \\
\text { breakdown } \\
\text { voltage at 30oC }\end{array}$ & $\begin{array}{l}\text { \% Moisture } \\
\text { expelled at } \\
150 \circ \mathrm{OC}\end{array}$ & $\begin{array}{l}\text { Pour point } \\
(\mathrm{oC})\end{array}$ & $\begin{array}{l}\text { Flash point } \\
\text { (oC) }\end{array}$ & $\begin{array}{l}\text { Peroxide } \\
\text { value } \\
(30 \text { days })\end{array}$ \\
\hline 1 & Transformer oil & $50 \mathrm{kv}$ & 20.11 & $\begin{array}{l}\text { Lower than } \\
\text { 0oC }\end{array}$ & 270 & 8.0 \\
\hline 2 & Palm kernel oil & $51 \mathrm{kv}$ & 11.83 & 30 & 346 & 15.0 \\
\hline 3 & Palm oil & $51 \mathrm{Kv}$ & 21.84 & 30 & 304 & 30.0 \\
\hline 4 & Groundnut oil & $30 \mathrm{Kv}$ & 8.9 & 28 & 340 & 16.0 \\
\hline 5 & Coconut oil & $4 \mathrm{Kv}$ & 14.3 & 30 & 340 & 28.0 \\
\hline
\end{tabular}




\subsection{RESULTS ANALYSIS}

The breakdown voltages for palm oil and the palm kernel oil are better than that of the transformer (mineral) oil. They have higher flash points than the transformer oil, but lower pour points. The palm and palm kernel oils can be comfortably used as transformer oil in the tropics without further treatment to reduce the pour points. For them to be used in the region where the ambient temperature is lower than $300 \mathrm{C}$, some form of treatment is required.

From table5, it is seen that there were some moisture in the samples. Perhaps better readings would have been obtained if they were completely demoisturized. Groundnut oil exhibited high flash point like the palm oils but have lower pour point. The breakdown voltage is $30 \mathrm{Kv}$; suggesting that it can also be used in high voltage system. The coconut oil can be limited to low voltage insulation. It can be used for impregnated paper/cloth insulation. More work is required on it to see how it can be treated to improve on its breakdown voltage value. Table 6 show some comparisons between the transformer oil and palm and palm kernel oils

Table 6: Comparison between transformer oil and palm/palm kernel oils

\begin{tabular}{|l|l|l|}
\hline Criteria & Mineral oil & Palm/palm kernel oils \\
\hline Source & $\begin{array}{l}\text { Seismic Product from petroleum } \\
\text { (mineral) }\end{array}$ & $\begin{array}{l}\text { Produced from economic trees } \\
\text { /farms }\end{array}$ \\
\hline Flammability & $\begin{array}{l}\text { Highly flammable. More flammable } \\
\text { than the palm oils }\end{array}$ & Less flammable than the mineral oil \\
\hline Effects on the environment & $\begin{array}{l}\text { Causes environmental and health } \\
\text { hazard: dangerous to crops and } \\
\text { aquatic lives. Accelerates corrosion }\end{array}$ & $\begin{array}{l}\text { Environmental friendly. Slows down } \\
\text { corrosion. Are biodegradable and } \\
\text { nontoxic. }\end{array}$ \\
\hline Cost & More expensive in Nigeria & Cheaper than mineral oil \\
\hline Effect to other insulating materials & $\begin{array}{l}\text { Accelerates aging of rubber, PVC } \\
\text { and most insulating materials }\end{array}$ & $\begin{array}{l}\text { More tolerable by other insulating } \\
\text { materials }\end{array}$ \\
\hline Pour point & $\begin{array}{l}\text { Has lower pour point than the palm } \\
\text { oils }\end{array}$ & $\begin{array}{l}\text { Have lower pour points than mineral } \\
\text { oil. }\end{array}$ \\
\hline Flash point & Has lower flash point & Have higher flash point \\
\hline
\end{tabular}

\subsubsection{PEROXIDE VALUES AND WATER CONTENT TESTS}

The test results for peroxide values for the samples are shown in figs4.1 to 4.6, for mineral transformer oil, groundnut oil, palm oil, coconut oil and palm kernel oil respectively. Fig 4.6 displays the values for all the oils for easy comparison. Figs 4.7 to 4.11 display the water content at various temperatures for transformer oil, groundnut oil, palm oil, coconut oil and palm kernel oil.

PEROXIDE VALUE/AGING GRAPHICAL ANALYSIS
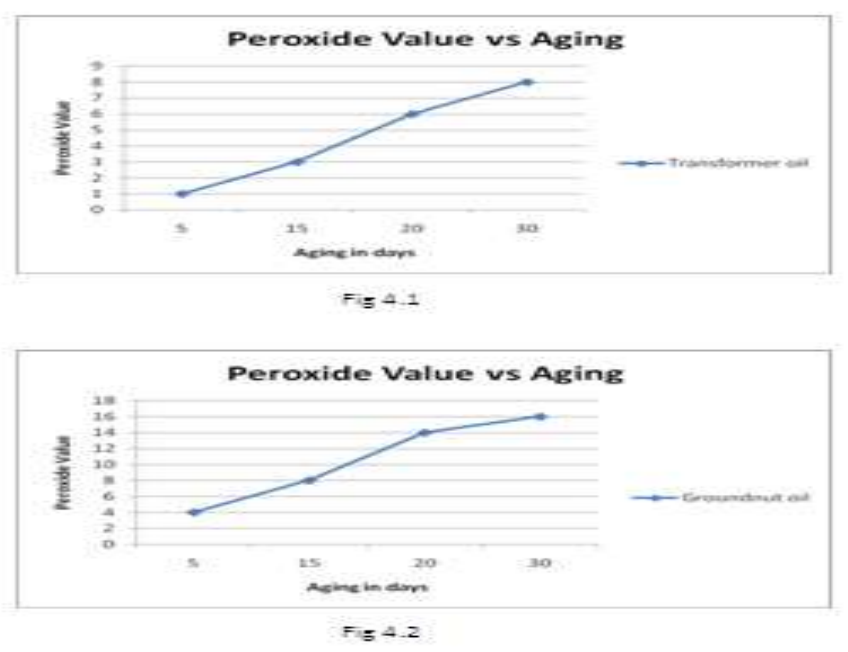

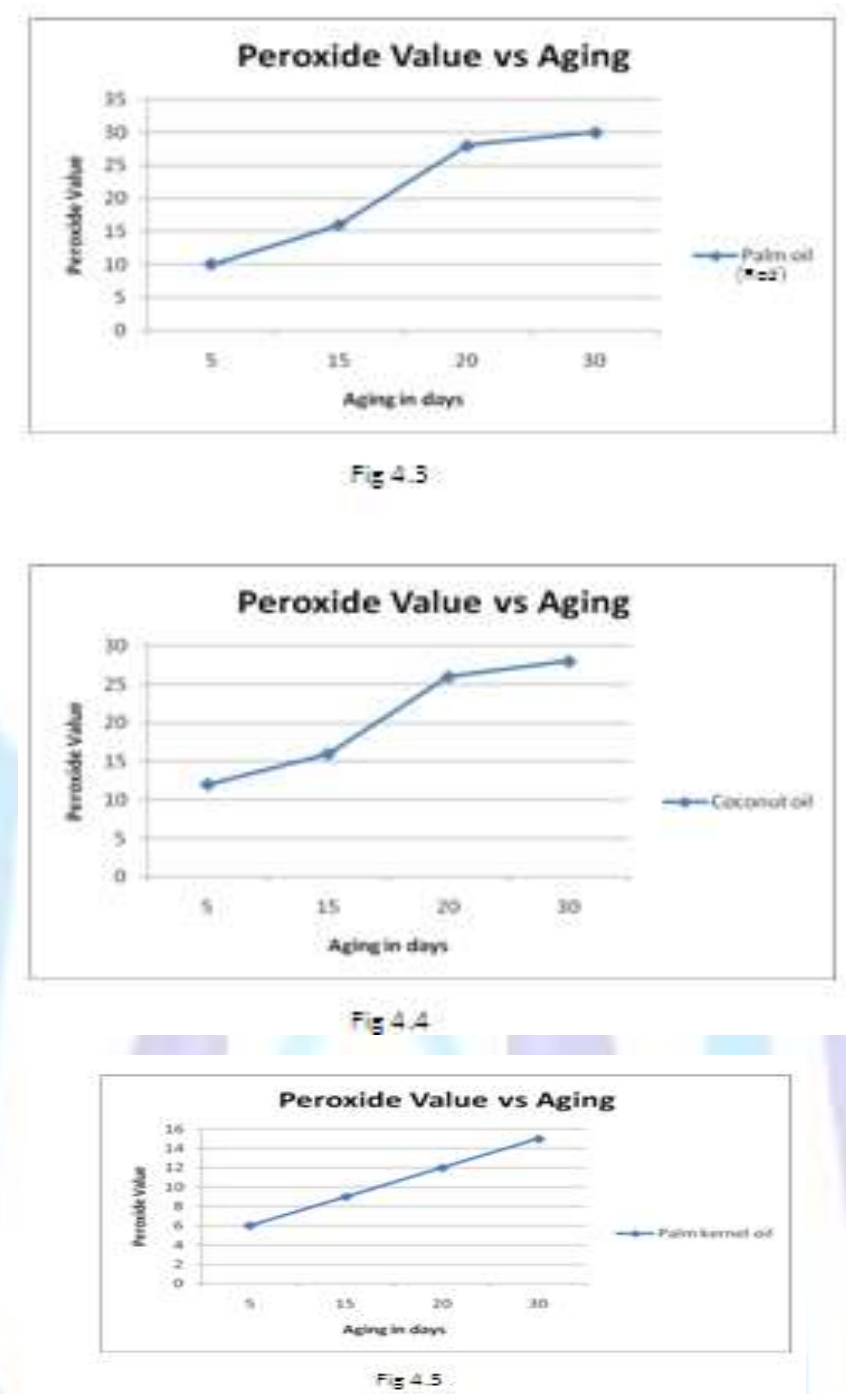

Peroxide Volue/Aging for all the Oil Somples Combined

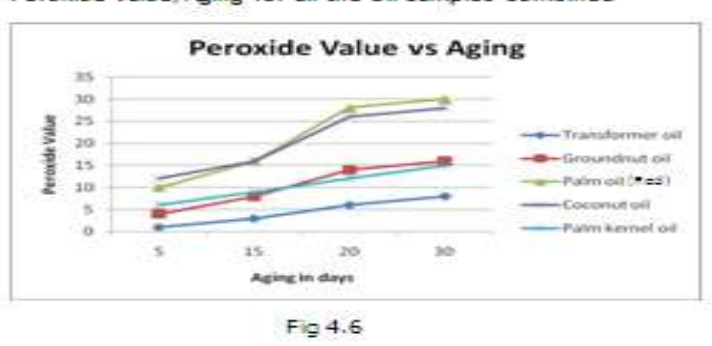

Moisture Content Vs Tempersture Grophical Anslysis

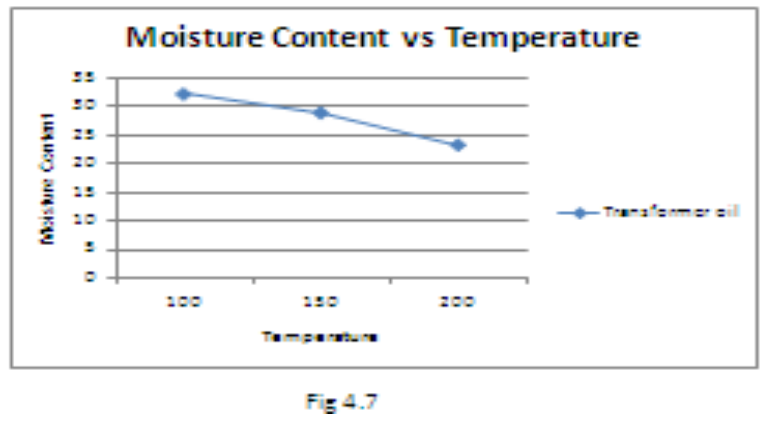



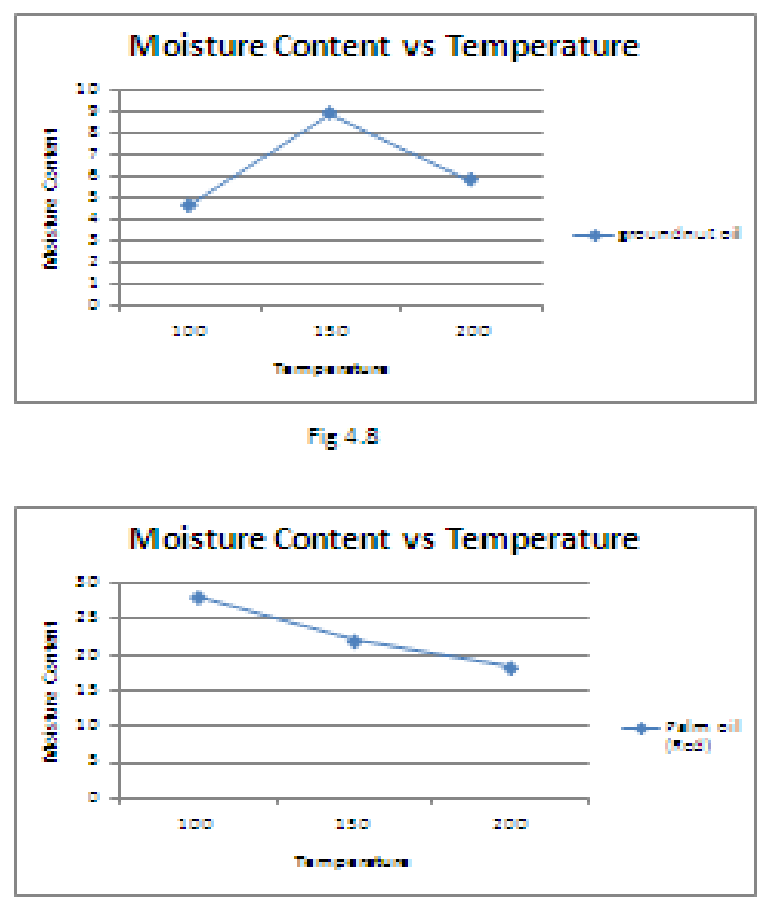

Fig 4.9

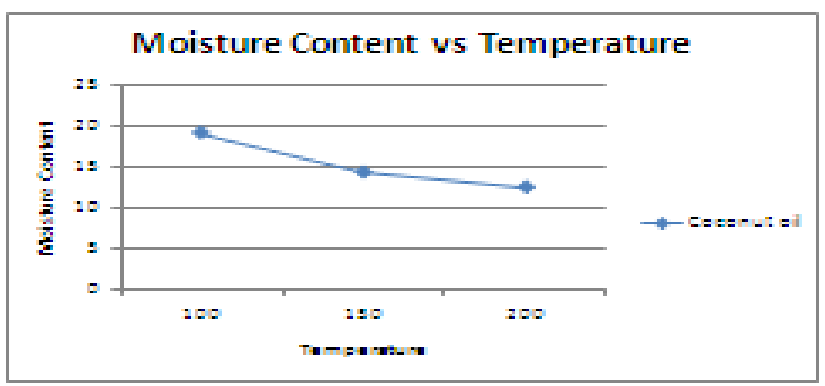

Fig 4.10

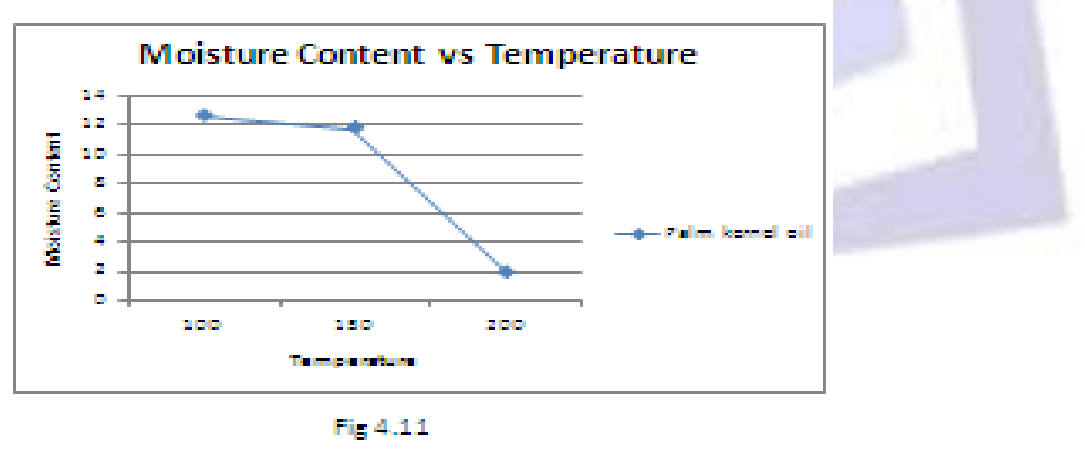

\subsubsection{BREAK-DOWN VOLTAGE (BDV) TESTS}

The results of the voltage breakdown tests are shown in figs 4.12 to 4.16 for mineral transformer oil, groundnut oil, palm oil, coconut oil and palm kernel oil respectively. Fig 4.17 shows the combined results for all of the oils for easy comparison. 


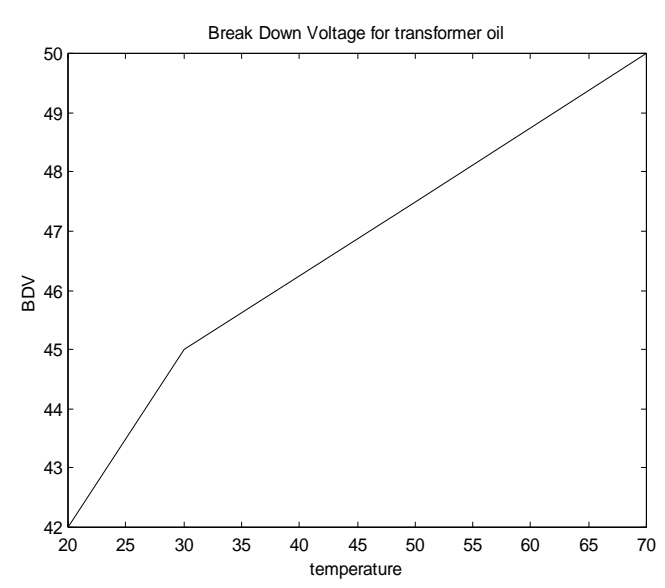

Fig 4.12: BDV for transformer oil

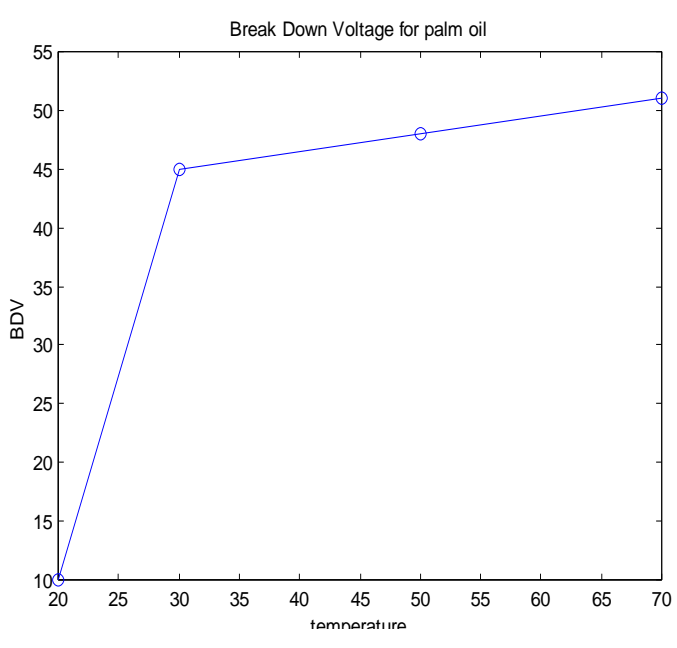

Fig 4.14: BDV for palm oil

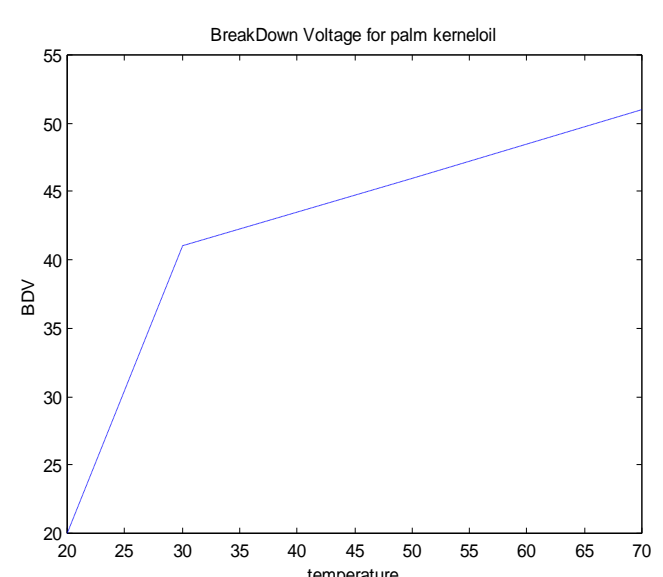

Fig 4.16: BDV for palm kernel oil

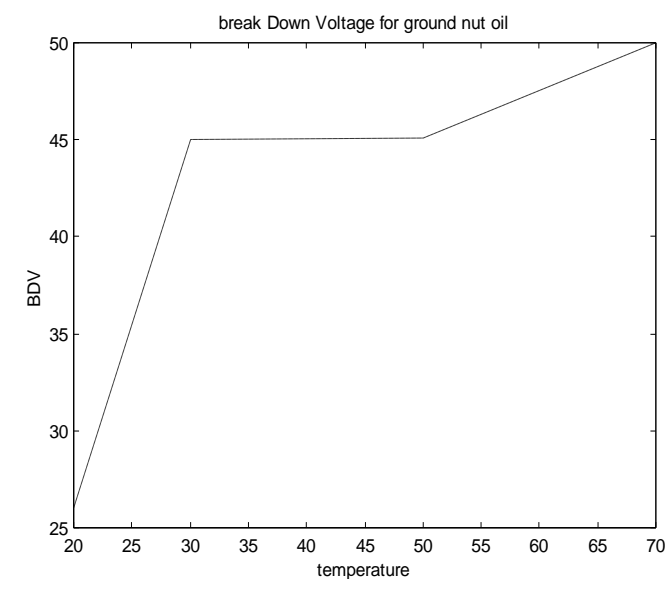

Fig 4.13: BDV for groundnut oil

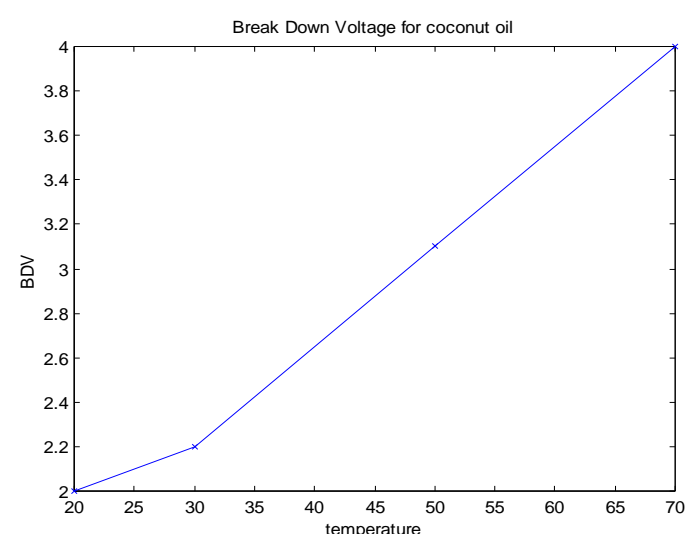

Fig 4.15: BDV for coconut oil

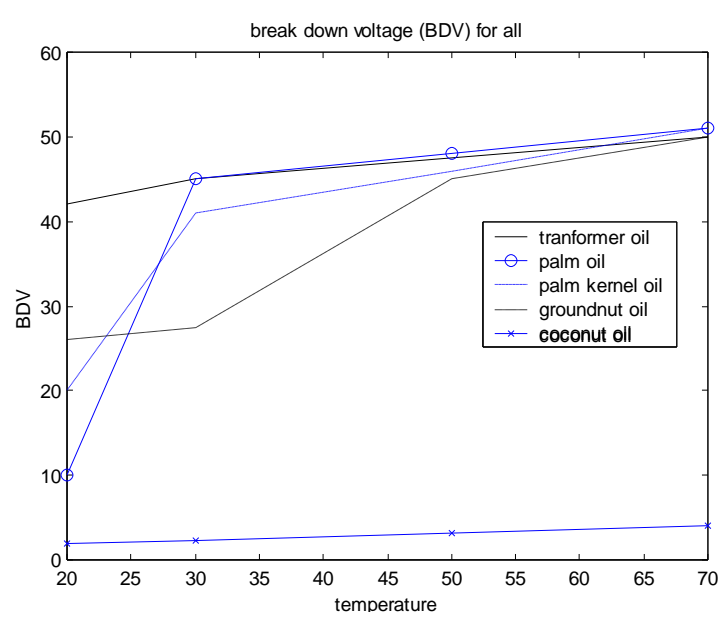

Fig 4.17: BDV for all the oils

be good replacement for it in terms of cooling and insulation.

The vegetable oil is biodegradable. So its spillage cannot be harmful to crops and aquatic lives unlike the mineral oil.

The dielectric strengths of all the oils are affected by Ingress of moisture but they can improve when moisture is removed.

The pour point of vegetable oil can be improved upon by special treatment. However, it can perform well at temperatures of 30 degrees and above. All the vegetable oils tested, exhibited better flash points than the transformer oil.

Palm oil, groundnut oil and palm kernel oil are very cheap (about $10 \%$ of that of mineral transformer oil) in Nigeria.

Coconut oil can be used for insulation in low voltage systems. 
More research work is going on in the areas of improving the other qualities of palm, palm kernel and groundnut oils. The coconut oil is also receiving attention on how its dielectric strength can be improved.

\section{REFERENCES}

Alt Energy Mag. Com, "What the Hack is a Smart Erid," 2001 $\mathrm{htt} / / \mathrm{www}$.altenergymag.com/articles/09.04.01/smartgrid/grid.ipg.

J.P. Crime", Newly Developed Analytical Techniques for charctaerization of Insulating Oils", in Electrical Insulating Oils, H.G. Erdman, Ed: ASTM, 1988.

T.V. Oommen, "Vegetable Oil for Liquid - Filled Transformers, IEEE - Electrical Insulation Magazine, 2002.

R. Eberhardt1, H.M. Muhr1, W. Lick1, F. Baumann2, "Campariso" of Alternative Insulating Fluids", IEEE - Annual report conference on Electrical Insulation Dielectric Phenomena. Pp.591-593 October 26 - 29, 2008.

P. McShane, "Relative properties of the New Combustion - Resistant Vegetable - Oil Based Dielectric Coolants for Distribution and Power Transformers" IEEE Transaction on Industry Applications, Vol.37, No. 4, pp 1132 - 1139 , July/August 2001.

B.Bhushan, Introduction to Tribology Wiley, 2002.

S.J. Randles, "Esters", in synthetics, Mineral Oils, and Bio-Based Lubricants: Chemistry and Technology, I.R. Rudnict, Ed. Florida: CRC Press, Taylor \& Francis Group, 2006.

B. Lloyd, "The End of Oil”, University of Otago July 2005.

D.P. Stockton, J.R. Bland, T.M. McClanahan, J. Wilson, D.L. Harris, and P. McShane, "Natural Ester Transformer Fluids: Safety, Reliability and Environment performance". IEEE - Petroleum and Chemical Industry Technical Conference, September 17 - 19, 2007.

R. Bartnikas, "Dielectrics and Insulation" in the Electrical Engineering Handbook Second Edition, R.C. Dorf, Ed: CC Press, 1997.

G. Daemisch, "Geriatrics of transformer.

M. Mirzai, A. Gholami, and F. Aminitar, "Failures Analysis and reliability calculation for power transformers", Journal of Electrical System, 2006.

"IEEE Guide for loading Mineral - Oil - Immersed Transformers", IEEE Std C57.91, 1995.

T.W. Dakin, "Electrical Insulation Deteriation Treated as a Chemical Reaction Rate Phenomenon", AlEE Transactions, Vol.66, pp.113 - 122, 1947.

"IEEE standard test procedure for thermal evaluation of oil - immersed distribution transformers", in IEEE std C57.100, 1986.

IEC, "IEC 61125 - Unused Hydrocarbon - based Insulating Liquids Test Methods for Evaluating the Oxidation Stability", 1992.

A. Bradwell, Electrical Insulation, London: Peter Peregrinus Ltd, 1983.

M. Koch, M. Fischer and S. Tenbohlen, "The breakdown Voltage of Insulation Oil under the Influence of Humidity, Acidity, Particles, and Pressure, International Conference APTADM, Poland, 2007. 